\title{
Potential of genetic resistance of new table grape hybrids to fungal pathogens
}

\author{
Elena Ilnitskaya*, Marina Makarkina, and Valeriy Petrov
}

Federal State Budget Scientific Institution «North Caucasian Federal Scientific Center of Horticulture, Viticulture, Wine-making», 39 str. 40 Let Pobedy, Krasnodar, 350901, Russia

\begin{abstract}
Downy mildew (Plasmopara viticola) and powdery mildew (Erysiphe necator) are the most common and economically significant fungal diseases in vineyards. The task of this work is to study the genotypes of new promising hybrid forms of table grapes for the presence of resistance genes to downy mildew (Rpv10 and Rpv3) and powdery mildew (Ren 9 ) using DNA-markers. The study was carried out on table grape hybrids under the working names Agat dubovskiy, Akelo, Arabella, Artek, Dubovskiy rozovyi, Gamlet, Ispolin, Kishmish dubovskiy, Kurazh, Pestryi, Valensiya and registered variety Liviya. The studied genes were analyzed using markers UDV305 and UDV737 (Rpv3), GF09-46 (Rpv10), CenGen6 (Ren9). The following cultivars were used as reference genotypes: Saperavi severnyi (carries Rpv10 gene) and Regent (Rpv3 and Ren9). It was established that $R p v 3$ gene is carried by hybrids Kishmish dubovskiy, Agat dubovskiy, Kurazh, Valensiya, Akelo, Gamlet, Dubovskiy rozovyi, Pestryi. Ren 9 gene was found in Artek, Agat dubovskiy, Kurazh, Ispolin, Valensiya, Arabella, Gamlet, Dubovskiy rozovyi, Pestryi. The Rpv10 gene was not detected in any of the analyzed grapevine samples. genotypes Agat dubovskiy, Kurazh, Gamlet, Dubovskiy rozovyi, Pestryi, Valensiya carry Rpv3 and Ren 9 genes simultaneously. These grapevines have an elegant bunch and large berries that are attractive to consumers.
\end{abstract}

\section{Introduction}

The development of DNA-marking methods has fundamentally changed the approaches to the classification and certification of varieties, the assessment of genetic diversity, mapping and identification of genes, genetic monitoring in genetics and breeding of cultivated plants. One of the areas of application of DNA-marker technologies is marker assisted selection (MAS), which allows identification and selection of genotypes carrying target genes, by passing phenotypic assessment, based only on DNA analysis data. DNA-markers are effectively used when working with grape genetic resources to study genetic diversity and biological potential, including resistance to the most harmful organisms.

DNA-markers identification of pathogen resistance genes in new breeding forms and grape varieties makes it possible to determine their adaptive potential to biotic stress factors. Downy mildew, caused by Plasmopara viticola, and powdery mildew, caused by Erysiphe

\footnotetext{
*Corresponding author: ilnitskaya79@mail.ru
} 
necator, are the most common and economically significant fungal diseases of the vine. The determination of resistance genes in grapevines to these pathogens is carried out mainly in all world scientific centers [1-9]. Identification of genes for resistance to downy mildew and powdery mildew in domestic material with the aim of creating stable ampelocenoses, preserving the harvest and extending the productive life of grape plantations is an urgent task.

For fresh consumption, people use table grapes. The requirements for modern grape varieties for fresh consumption concern both the kind of the product (the size of the bunch, the size and shape of the berries, the color of the skin of the berries), its taste characteristics, as well as the transportability and suitability for storing the harvest, the processability of plantings and resistance to biotic and abiotic stressors. The resistance of the variety to pathogens allows to reduce chemical treatments during the growing process, which makes it possible to obtain environmentally safe products.

The task of this work was to study the genotypes of new promising table grapes hybrid forms for the presence of downy mildew (Rpv10 and Rpv3) and powdery mildew (Ren 9 ) resistance genes using DNA markers.

\section{Materials and Methods}

The study was performed on hybrid forms of table grapes under working names Agat dubovskiy, Akelo, Arabella, Artek, Dubovskiy rozovyi, Gamlet, Ispolin, Kishmish dubovskiy, Kurazh, Pestryi, Valensiya and the registered variety Liviya. The following cultivars were used as reference genotypes: Saperavi severnyi (carries Rpv10 gene) and Regent (Rpv3 and $\operatorname{Ren} 9$ ). [10-12].

Molecular genetic studies were carried out by the method of polymerase chain reaction (PCR) with the analysis of the results by the method of fragment analysis on an automatic genetic analyzer. DNA was extracted from young leaves of the apical part of the shoots by CTAB method [13].

PCR was carried out in a $20 \mu \mathrm{L}$ reaction mixture containing nearly $50 \mathrm{ng}$ of genomic DNA, 1.5 units of Tag polymerase, $1 \mathrm{x}$ buffer for Tag polymerase with ammonium sulfate and magnesium, $2 \mathrm{mM} \mathrm{MgCl} 2,0.2 \mathrm{mM}$ each dNTP (deoxynucleotide triphosphates) (SibEnzyme-M, Moscow) and $200 \mu \mathrm{M}$ of each primer (Syntol, Moscow) using a BioRad device (USA).

$R p v 3$ gene was analyzed using markers UDV305 and UDV737 [14], according to the following protocol: initial denaturation -5 minutes at $+95{ }^{\circ} \mathrm{C}$; then 34 cycles of synthesis: denaturation - 10 seconds at $+95^{\circ} \mathrm{C}$, annealing of primers - 30 seconds at $+55^{\circ} \mathrm{C}$, elongation - 30 seconds at $+72^{\circ} \mathrm{C}$; the final cycle (final elongation) - 3 minutes at $+72^{\circ} \mathrm{C}$.

The allelic status of $R p v 10$ gene was diagnosed using the marker GF09-46 [15] according to the following scheme: initial denaturation - 5 minutes at $+95{ }^{\circ} \mathrm{C}$; then 40 cycles of synthesis: denaturation -30 seconds at $+95^{\circ} \mathrm{C}$, annealing of primers -30 seconds at $+60{ }^{\circ} \mathrm{C}$, elongation - 40 seconds at $+72^{\circ} \mathrm{C}$; the final cycle (final elongation) - 5 minutes at $+72{ }^{\circ} \mathrm{C}$.

Gene Ren 9 was identified using CenGen6 marker [11] by the following protocol: initial denaturation -5 minutes at $+95^{\circ} \mathrm{C}$; then 34 cycles of synthesis: denaturation - 10 seconds at $+95{ }^{\circ} \mathrm{C}$, annealing of primers -30 seconds at $+55^{\circ} \mathrm{C}$, elongation -30 seconds at $+72{ }^{\circ} \mathrm{C}$; the final cycle (final elongation) -3 minutes at $+72^{\circ} \mathrm{C}$.

Sequences of marker oligonucleotides were synthesized with fluorescent labels: FAM UDV737, R6G - UDV305, GF09-46, CenGen6. 


\section{Results and Discussion}

Table grape genotypes Agat dubovskiy, Akelo, Arabella, Artek, Dubovskiy rozovyi, Gamlet, Ispolin, Kishmish dubovskiy, Kurazh, Pestryi, Valensiya, Liviya were studied by DNAmarkers for the presence of two downy mildew resistance genes (Rpv10 and Rpv3) and one powdery mildew resistance gene (Ren 9). Ren 9 and Rpv3 genes are inherited from North American grape species, gen $R p v 10$ - from V.amurensis, in the pedigrees of the studied grape genotypes, both species are found.

For the detection of Rpvl0 gene, the GF09-46 marker was used [15], target PCR fragment indicating the presence of resistance allele did not found in any analyzed genotype (Table).

Table. The presence of resistance genes to downy mildew and powdery mildew

\begin{tabular}{|l|c|c|c|}
\hline \multicolumn{1}{|c|}{ Cultivars } & \multicolumn{2}{c|}{ Genes } \\
\cline { 2 - 4 } & Rpv10 & Rpv3 & Ren9 \\
\hline $\begin{array}{l}\text { Artek } \\
\text { (Yubiley Novocherkasska x Muskat letniy) }\end{array}$ & - & - & + \\
\hline $\begin{array}{l}\text { Kishmish dubovskiy } \\
\text { (Nimrang x Kishmish luchistyi) }\end{array}$ & - & + & - \\
\hline $\begin{array}{l}\text { Agat dubovskiy } \\
\text { (Talisman x Kuban') }\end{array}$ & - & + & + \\
\hline $\begin{array}{l}\text { Kurazh } \\
\text { (Vostorg Krasnyi x Yubiley Novocherkasska) }\end{array}$ & - & + & + \\
\hline $\begin{array}{l}\text { Ispolin } \\
\text { (Flamingo x Rochefort) }\end{array}$ & - & - & + \\
\hline $\begin{array}{l}\text { Valensiya } \\
\text { (Vostorg krasnyi x Yubiley Novocherkasska) }\end{array}$ & - & + & + \\
\hline $\begin{array}{l}\text { Akelo } \\
\text { (Vostorg x Kodryanka) }\end{array}$ & - & + & - \\
\hline $\begin{array}{l}\text { Arabella } \\
\text { (Talisman x Rishel'ye) }\end{array}$ & - & - & + \\
\hline $\begin{array}{l}\text { Gamlet } \\
\text { (Vostorg krasnyi x Tason) }\end{array}$ & - & + & + \\
\hline $\begin{array}{l}\text { Dubovskiy rozovyi } \\
\text { (Vostorg Krasnyi x Yubiley Novocherkasska) }\end{array}$ & - & + & + \\
\hline $\begin{array}{l}\text { Pestryi } \\
\text { (Talisman x Kishmish luchistyy) }\end{array}$ & - & + \\
\hline $\begin{array}{l}\text { Liviya } \\
\text { (Flamingo x Arkadiya) }\end{array}$ & - & + \\
\hline
\end{tabular}

DNA-markers UDV737 and UDV305 were used to determine the allelic status of Rpv3 locus [14]. It is known that $R p v 3$ has 7 haplotypes that give resistance to Plasmopara viticola. Only one haplotype $R p v 3^{299-279}$ was identified in the studied grapevine forms, we found it in genotypes Kishmish dubovskiy, Agat dubovskiy, Kurazh, Valensiya, Akelo, Gamlet, Dubovskiy rozovyi, Pestryi (Table).

The CenGen6 marker was used to identify Ren9 gene [11]. Target fragment $287 \mathrm{bp}$ detected when analyzing genotypes Artek, Agat dubovskiy, Kurazh, Ispolin, Valensiya, Akelo, Arabella, Gamlet, Dubovskiy rozovyi, Pestryi. 
In the genotype of control variety Livia, with which the studied new grapevine hybrid forms are compared for complex of economically valuable traits, none of the analyzed resistance loci was found.

\section{Conclusion}

As a result of the DNA-marker analysis, it was found that $R p v 3$ gene is present in grapevine hybrids Kishmish dubovskiy, Agat dubovskiy, Kurazh, Valensiya, Akelo, Gamlet, Dubovskiy rozovyi, Pestryi (table). The powdery mildew resistance gene Ren 9 was found in the following forms: Artek, Agat dubovskiy, Kurazh, Ispolin, Valensiya, Arabella, Gamlet, Dubovskiy rozovyi, Pestryi. The $R p v 10$ gene was not detected in any of the analyzed samples. Of the new hybrid forms of table grapes, the Rpv3 and Ren 9 genes simultaneously carry the genotypes Agat dubovskiy, Kurazh, Gamlet, Dubovskiy rozovyi, Pestryi, Valensiya. These grapevine forms have beautiful, attractive bunch for the consumer and large berry (fig.). They are promising for further study and for use in following breeding.

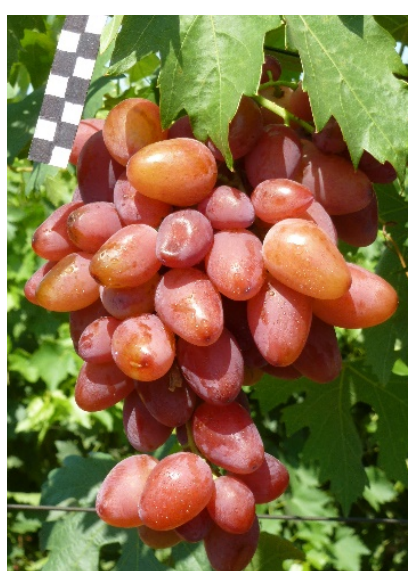

Gamlet

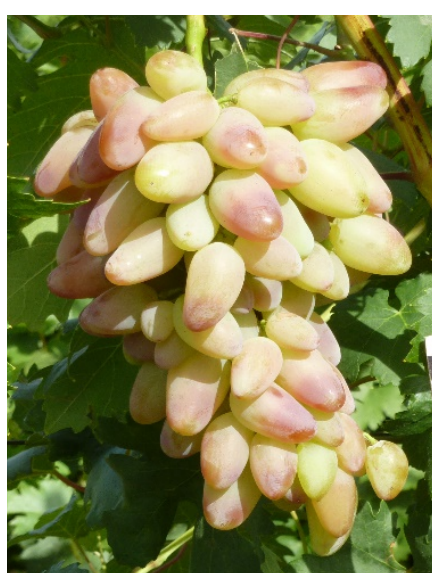

Kurazh

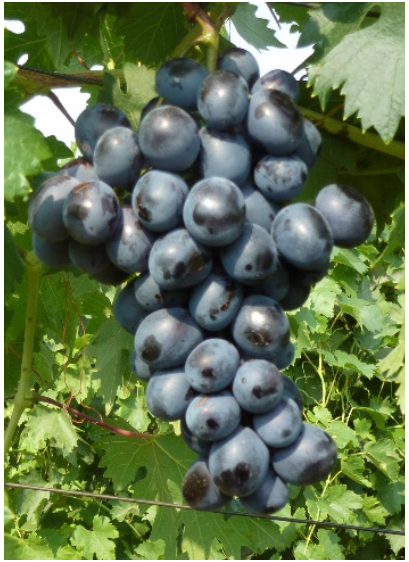

Agat dubovskiy

Fig. Bunches of the studied forms of grapes

Acknowledgments. The study was carried out with the financial support of the Kuban Science Foundation within the framework of the scientific project No. MFI-20.1 / 20

\section{References}

1. K. Kosev, I. Simeonov, M. Ivanov, Z. Nakov, T. Hvarleva, Biotechnol. Biotechnol. Equip., 31(1), 68-74 (2017) https://doi.org/10.1080/13102818.2016.1259019

2. D. Merdinoglu, C. Schneider, E. Prado, S. Wiedemann-Merdinoglu, P. Mestre, OENO one, 52(3), 203-209 (2018) https://doi.org/10.20870/oeno-one.2018.52.3.2116

3. S. Vezzulli, A. Vecchione, M. Stefanini, L. Zulini, Eur. J. Plant Pathol., 150(2), 485-495 (2018)

4. S. Foria, C. Monte, R. Testolin, G. di Gaspero, G. Cipriani, Acta Hortic., 1248, 549-554 (2019) http://doi.org/10.17660/ActaHortic.2019.1248.73

5. E. Zini, C. Dolzani, M. Stefanini, V. Gratl, P. Bettinelli, D. Nicolini, G. Betta, C. Dorigatti, R. Velasco, T. Letschka, S. Vezzulli, Int. J. Mol. Sci., 20(14), 3526 (2019) https://doi.org/10.3390/ijms20143526 
6. S. Vezzulli, C. Dolzani, D. Nicolini, P. Bettinelli, D. Migliaro, V. Gratl, T. Stedile, A. Zatelli, M. Dallaserra, S. Clementi, C. Dorigatti., R. Velasco, L. Zulini, M. Stefanini, BIO Web Conf., 13, 01002 (2019) https://doi.org/10.1051/bioconf/20191301002

7. Z. Yıldırım, A. Atak, M. Akkurt, Ciência Téc. Vitiv., 34(1), 15-24 (2019) https://doi.org/10.1051/ctv/20193401015

8. M. L. Prazzoli, S. Lorenzi, M. Perazzolli, S. Toffolatti, O. Failla, M. S. Grando, BIO Web Conf., 13, 01004 (2019) https://doi.org/10.1051/bioconf/20191301004

9. S. Riaz, C. M. Menéndez, A. Tenscher, D. Pap, M. A. Walker, Hortic. Res., 7(1), 104 (2020) https://doi.org/10.1038/s41438-020-0335-Z

10. E.T. Ilnitskaya, S.V. Tokmakov, L.G. Naumova, Scientific life, 2, 119-124 (2018)

11. C. J. van Heerden, P. Burger, A. Vermeulen, R. Prins, Euphytica, 200(2), 281-295 (2014) https://doi.org/10.1007/s10681-014-1167-4

12. D. Zendler, R. Töpfer, E. Zyprian, Plants, 10(1), 24 (2021) https://doi.org/10.3390/plants10010024

13. S. L. Piccolo, A. Alfonzo, G. Conigliaro, G. Moschetti, S. Burruano, A. Barone, Afr. J. Biotechnol.,11(45), 10305-10309 (2012) https://doi.org/10.5897/AJB11.3023

14. G. di Gaspero, D. Copetti, C. Coleman, S.D. Castellarin, R. Eibach, P. Kozma, T. Lacombe, G. Gambetta, A. Zvyagin, P. Cindrić, L. Kovács, M. Morgante, R. Testolin, Theor. Appl. Genet., 124(2), 277-286 (2012) http://dx.doi.org/10.1007/s00122-0111703-8

15. F. Schwander, R. Eibach, I. Fechter, L. Hausmann, E. Zyprian, R. Töpfer, Theor. Appl. Genet., 124(1), 163-176 (2012) http://doi.org/10.1007/s00122-011-1695-4 